\title{
Biostratigraphy or biochronology? Lessons from the Early and Middle Miocene small Mammal Events in Europe
}

\author{
Biostratigraphie ou biochronologie ? Leçons des événements à petits mammifères du Miocène \\ inférieur et moyen en Europe
}

\author{
Albert J. van der Meulen a , Israel García-Paredes ${ }^{\text {b,c }}$, M.Ángeles Álvarez-Sierra ${ }^{\mathrm{d}}$, \\ Lars W. van den Hoek Ostende ${ }^{\mathrm{c}}$, Kees Hordijk ${ }^{\mathrm{a}}$, Adriana Oliver ${ }^{\mathrm{b}}$, Paloma López-Guerrero ${ }^{\mathrm{d}}$, \\ Verónica Hernández-Ballarín ${ }^{\mathrm{b}}$, Pablo Peláez-Campomanes ${ }^{\mathrm{b}, *}$ \\ ${ }^{a}$ Institute of Earth Sciences, Utrecht University, Budapestlaan 4, 3584 CD Utrecht, The Netherlands

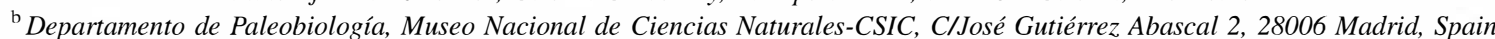 \\ ${ }^{\mathrm{c}}$ Netherlands Centre for Biodiversity-Naturalis, Darwinweg 2, 2333 CR Leiden, The Netherlands \\ - Departamento/UEI de Paleontología, Facultad de Ciencias Geológicas, Universidad Complutense e Instituto de Geología Económica \\ (CSIC-UCM), C/José Antonio Novais 2, 28040 Madrid, Spain
}

\begin{abstract}
Since the proposition in 1975 of the European Neogene Mammal (MN) scale by Pierre Mein, the amount of taxonomical, stratigraphical and chronological information around Europe has increased exponentially. In this paper, the stratigraphical schemes of three of the best studied areas for the Lower and Middle Miocene, the Aragonian type area in Spain and the Upper Freshwater Molasse from the North Alpine Foreland Basin in Switzerland and Bavaria, are compared. The correlation of their local biostratigraphies are discussed. Sixteen rodent's events are studied and ranked in the three areas according to their local biostratigraphy. This study shows, and quantifies for the first time, the significant asynchronies of the different included rodent events. The MN-system is discussed in the light of those results. In accordance, we propose that it is still useful but only in a biochronological way, as a sequence of time-ordered reference localities allowing coarse long-distance correlations. In order to obtain better temporal resolution, this system has to be combined with local biostratigraphies that are well calibrated to the time scale, implementing the information about synchrony and diachrony of mammal events in different areas.
\end{abstract}

Keywords: Rodentia; Chronology; MN-system; Asynchrony; Central Europe; Spain

\section{Résumé}

Depuis la proposition par Pierre Mein, en 1975, de l'échelle des mammifères néogènes d'Europe (MN), la quantité d'information taxinomique, stratigraphique et chronologique en Europe a augmenté exponentiellement. Dans cet article, les séquences stratigraphiques de trois des régions les plus étudiées pour le Miocène inférieur et moyen, la région-type de l'Aragonien en Espagne et la Molasse supérieure du Bassin Nord-Alpin en Suisse et en Bavière, sont comparées, et la corrélation de leurs biostratigraphies localesdiscutée. Seize événements àrongeur sont étudiés et ordonnés dans les trois régions d'après leur biostratigraphie locale. Cette étude montre et quantifie pour la première fois, les importantes asynchronies de ces différents événements. Le système MN est discuté à la lumière de ces résultats. En conséquence, nous proposons que ce système reste utile seulement d'un point de vue biochronologique, comme séquence ordonnée dans le temps de localités-repères permettant des corrélations grossières à longue distance. Afin d'obtenir une meilleure résolution temporelle, ce système doit être combiné avec des biostratigraphies locales bien calibrées dans le temps, en intégrant les informations de synchronie et de diachronie des événements à mammifères dans différentes régions. 


\section{Introduction}

The non-recurrent compositional and evolutionary changes -f the European mammal fauna history have been extensively used as a relative-age tool for the continental sediments in which they are found. Based on these characteristics, Mein (1975a, 1975b) proposed the subdivision of the MiocenePliøcene record int 17 successive Mediterranean Neøene units based on mammals (MN). The strength $\bullet$ this scheme lies in its simplicity and it is one of the reasons why the MN-system has become the primary biochronological framework for faunal correlation of the European Nenene. After 35 years, the system still facilitates communication between scientists working in different regions, and doubtlessly it contributed a

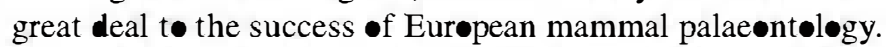

The MN-system has been extensively used for correlations from local to continental scale, although not always with the same philosøphy (De Bruijn et al., 1992). Thus, variøus authors consider the MN-system as biostratigraphical (e.g., Steininger, 1999; Agustí et al., 2001), while according t॰ others it should be used as a biochronølogical scheme (De Bruijn et al., 1992; Van Dam, 2003). Using the $\mathrm{MN}$-system as a biostratigraphical scheme is in itself tempting, given the exponential increase of the stratigraphical information. However, biostratigraphy involves not only the fossil content but als the bodies of røck that include it. Therefore, in our •pinion, the MN-system as defined by Mein (1975a, 1975b) and modified by the Regional Committee on Mediterranean Neogene Stratigraphy (RCMNS; De Bruijn et al., 1992) can never be considered as a biostratigraphical scale, because it is exclusively based on fossil associations and the biological evolution that they reflect (Fahlbusch, 1991; Van Dam et al., 2001).

Since the introduction of the $\mathbf{M N}$-system, the number of localities has søared. Hundreds of publications have tightened

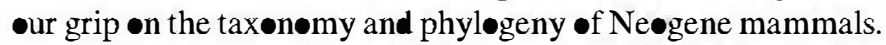

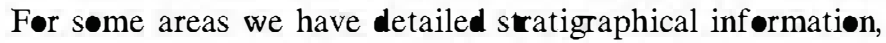
allowing us tø track faunal develøpment t• a degree unheard of in 1975. This increase in the local biestratigraphical knowledge and the recognition of the different $\mathrm{MN}$ units in various geographical regions, have resulted in the local recognition of 'MN boundaries' and the assignation of very different ages for each of them (Bølliger, 1997; Heissig, 1997; Kälin, 1997; Kempf et al., 1997; Daams et al., 1999a, 1999b; Agustí et al., 2001; Abdul Aziz et al., 2008, 2009; Kälin and Kempf, 2009). Møst of those boundaries between successive MN units have been characterize by a single or a combination of biøevents that were not necessarily always coincident in the different regions.

In •rder to avoid circular reasøning on the isøchrony or diachrony of any faunal event, the mammal history $\bullet b v i \bullet u s l y$ has to be independently calibrated the time scale. Such calibrations (usually palaeomagnetical or radiometrical) are local by definition because they are based on properties of the røcks from which the fossils derive, or from other røcks with which they are closely associated. The distribution of both localities and mammal taxa is patchy in space as well as in time; consequently, the locally-øbtained ages for first and last -ccurrences $\bullet$ taxa (FO's and LO's, respectively), used as dates for continent-wide immigrations and extinctions, are a priøri t॰ be mistrusted as long as synchrony and/or diachrøny of the various events have not been demonstrated.

In order to demonstrate the synchrony or diachrony of bioevents and its magnitude, we analyze and discuss the sequence and timing of several small mammal events recognizable in areas were an independent calibration to the time scale has been proposed, and compare them with what can be $\bullet$ bserved in $\bullet$ ther Eurøpean records. Previøus to this main gøal we discuss the chrøn॰logies established for three different Early and Middle Miecene micromammal records: the Aragønian type area in north Central Spain (Daams et al., 1999a; Van der Meulen et al., 2005, in press; Van Dam et al., 2006); the Upper Freshwater Molasse (OSM) of the North Alpine Foreland Basin (NAFB) in Switzerland, recently updated by Kälin and Kempf (2009); and the OSM of the North NAFB in Bavaria, Germany (Abdul Aziz et al., 2008, 2009). Probable correlations between existing løcal biøstratigraphies are suggested. Finally, we discuss the different approaches to the Eurøpean mammal chronølogy, paying special attention to the original definition and current uses of the $\mathrm{MN}$-system.

\section{Chronology of local biostratigraphies}

Irrespective of whether one is interested in long distance correlations or in the regional faunal history, each study tracking changes through time starts with establishing a local biostratigraphy, necessarily linked to the løcal lithostratigraphical record,

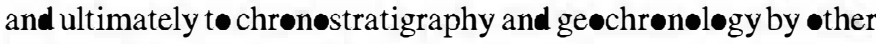
independent stratigraphical disciplines (magnetostratigraphy, cyclostratigraphy, etc.). Despite the recent increase of new independent correlations to the time scale, there still exists a strong need of spatially distributed absolute dates (Van Dam, 2003). Moreover, in •ur •pinion, a number of the existing numerical age determinations are not rigorous enough to be reliable (Daams et al., 1999b). This is due to the use of:

- second or third order correlations;

- radiometric ages with very large uncertainty intervals;

- insufficient number of recorded palaemagnetical chrons, making independent correlation t॰ the Geømagnetic P॰larity Time Scale (GPTS) impossible;

- the use of pøor-quality pølarity signals.

In Europe, there are three overlapping Lower to Middle Miøcene records that have been tied the time scale, at least in a large part:

- the record of the Aragønian type area in north Central Spain (Daams et al., 1999a; Van der Meulen et al., 2005, in press; Van Dam et al., 2006);

- the mammal fauna sequence from the Upper Freshwater Molasse (OSM) of the North Alpine Foreland Basin in Switzerland (B•lliger, 1997; Kälin, 1997; Kempf et al., 1997; Kälin and Kempf, 2009); 
- the OSM in Bavaria, Germany (Abdul Aziz et al., 2008, 2009).

The three records represent twø different biøprøvinces and provide a unique opportunity to compare different faunal histories through time, as shown by Kälin and Kempf (2009). Løcal biostratigraphical schemes have been proposed for each -f the three areas considered in this study (Heissig, 1997; Daams et al., 1998, 1999a; Böhme et al., 2002; Abdul Aziz et al., 2008; Kälin and Kempf, 2009; Van der Meulen et al., in press). Fig. 1 shows the proposed correlations of the compared Eurøpean records to the Astronomical Tuned Neøgene Time Scale (ATNTS2004; Lourens et al., 2004).

\subsection{Aragonian type area}

The Aragønian type section and its directly adjacent areas have yielded a detailed micromammal faunal succession, which stands out as $\bullet$ ne $\bullet$ the best kn॰wn terrestrial records frøm the Eurøpean Early tø Middle Miøcene. Since the overview of Daams et al. (1999a) new data from the Aragonian type area (Calatayud-Møntalbán basin) have becœme available: e.g., revision of the sciurid Atlantoxerus by Peláez-Campomanes
(2001), medium-sized Democricetodon by Van der Meulen et al. (2003), Gliridae from the Early and Middle Aragønian (García-Paredes, 2006; García-Paredes et al., 2009, 2010), Megacricetodon from several localities (now in progress, and Oliver Pérez et al., 2008; Oliver et al., 2009), the revision of the Eømyidae by Álvarez-Sierra (now in progress), the revision of the Aragønian Ochøtonidae by Hordijk (now in progress) and the revision of insectivores (nøw in progress, and Van den Hoek Ostende and Furi6, 2005; Van den Hoek Ostende et al., 2009). The new taxonomical information and stratigraphical distribution of lower and middle Aragonian faunas are summarized in Van der Meulen et al. (in press). Younger faunas from the Calatayud-Montalbán basin are currently under study by López Guerrerø; the results will lead to a revision of the upper Aragønian and lower Vallesian biestratigraphy.

Daams et al. (1999a) proposed the last Aragønian chron- logical framework included in Fig. 1 based on the reinterpretation of the biostratigraphical correlation between the Armantes and Vargas sections (Daams et al., 1999b), which are tw॰ •f the four high-reselution sections in the Calatayud-Montalbán basin correlated magnetostratigraphically to the GPTS (Krijgsman et al., 1994, 1996). In this paper we use the recalibrated ages of the faunas proposed by Van Dam et al. (2006) in accordance to

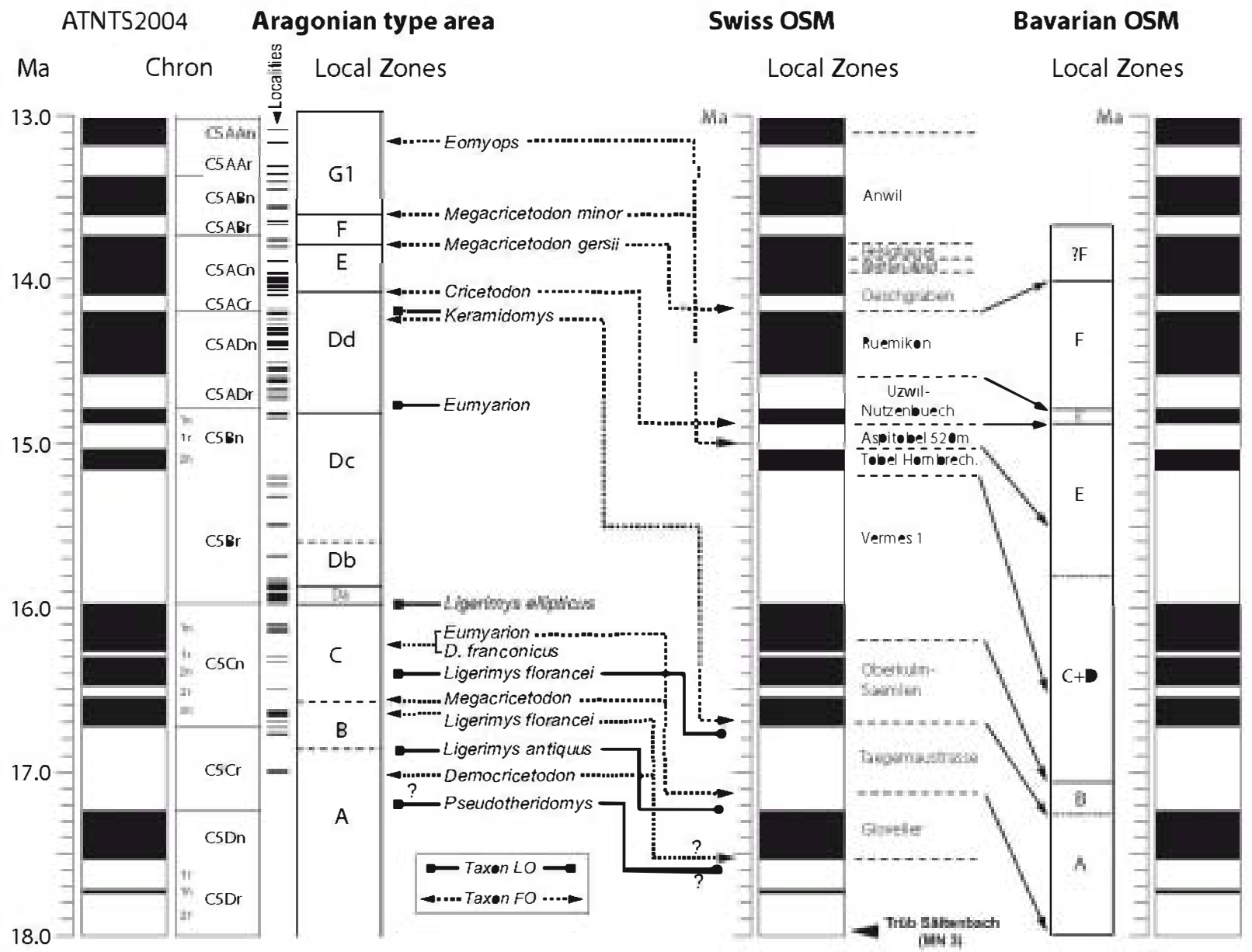

Fig. 1. Proposed correlations of the three compared European records to the ATNTS2004 (Lourens et al., 2004): Aragonian type area in North Cen et al., 1999a; Van Dam et al., 2006), the Upper Freshwater Molasse of the North Alpine Foreland Basin in Switzerland (Kälin and Kempf, 2009), and the Upper Freshwater Molasse in Bavaria (Abul-Aziz et al., 2009). 
the ATNTS2004 (Løurens et al., 2004). All chrons from the upper half of C5Cn.1n to C5AAn have been recognized in the Aragønian type area, providing reliable constraints for the ages

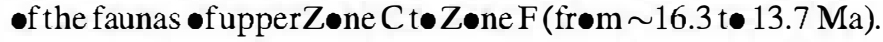

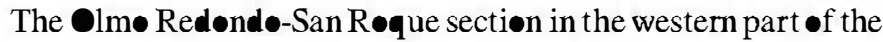
type area (Daams et al., 1999a), containing few meters of the uppermost Ramblian and the lowermost part of the Aragønian, has not yet been analyzed palaemagnetically. This section includes the lower part of the Vargas-Valdemoros sedimentary unit, and represents uppermost Zøne A, Zøne B, and lower Zone $C$. The numerical ages of these faunas and the biozone boundaries are based on sedimentary rates obtained in the -verlaying sediments that were analyzed palaemagnetically.

The beginning $\bullet$ the Aragønian (Zøne B) is recognized by the First Common Occurrence (FCO) of Democricetodon hispanicus, which is found in the løcality San Røque 1 frøm the

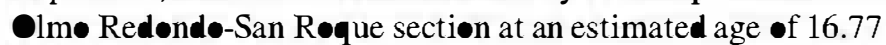
Ma. Tøgether with the age of San Røque 4B (SR4B, uppermøst Zone A, upper Ramblian) in the same section, the lower boundary of the Aragonian is constrained by the estimated ages -f 16.99-16.77 Ma. Democricetodon hispanicus is present with very low numbers in San Røque 4B and San Røque 4A ( 17.0 $\mathrm{Ma}$ ), and constitutes the $\bullet$ ldest $\bullet$ ccurrence $\bullet$ the genus with an estimated age in Spain. The mentioned ages indicate that the entry and increase in relative abundance of the genus in the Aragønian area took place in the late Ramblian during chron C5Cr (17.235-16.721 Ma, ATNTS2004).

The beginning $\bullet$ the Middle Aragønian (Zøne Da) is easily recognize by the rapid decrease and extinction of the eomyid Ligerimys ellipticus, which is a common todominant tax $\bullet$ in Zone C. The extinction takes place between Vargas 2A and Vargas 2B (3 m above Vargas 2A) in the Vargas section, which constrains the Early-Middle Aragønian boundary to 15.94$15.92 \mathrm{Ma}$. The lowermost fauna ( $\mathrm{La} \mathrm{C} \bullet \mathrm{A}) \bullet f$ the $\mathrm{La} \mathrm{C} \bullet$ section (not analyzed palaemagnetically) contains less than $1 \% \bullet$ L ellipticus; $\bullet$ therwise its comp sition is typical $\bullet$ Z Zne $\mathrm{Da}$. Theref $\bullet$, La Cøl A has been biostratigraphically situated between Vargas 2A, in which 22\% of the rodent teeth belong to L ellipticus, and Vargas 2B, in which the emyids are absent. This leads tø an estimated age $\bullet 15.93 \mathrm{Ma}$ f $\bullet \mathrm{La} \mathrm{C} \bullet \mathrm{A}$, and the Early-Middle Aragønian bøundary may be constrained further to 15.935 Ma. Magnetostratigraphical calibration shows that the boundary lies close to the lower boundary of chron C5Br (15.974-15.032 Ma, ATNTS2004; Daams et al., 1999a).

The Middle-Late Aragønian bøundary, equivalent t• the Zone E-Zone F boundary, is drawn in the magnetostratigraphically calibrated type section itself, between the localities Las Umbrías 20 and Las Umbrías 22 (Daams et al., 1999a), which have an age of $13.80 \mathrm{Ma}$ and $13.76 \mathrm{Ma}$, respectively (Van Dam et al., 2006). According to Krijgsman et al. (1996) the boundary lies about 1/10 below the top of chron C5ACn (14.095-13.688 Ma, ATNTS2004; Abels et al., 2005). Since we use here the revised age of the top $\bullet$ chron C5ACn (Abels et al., 2005) the Middle-Late Aragonian boundary is slightly younger than in Krijgsman et al. (1996).

The magnetostratigraphical calibrations alløw correlation of the Aragøian to the ATNTS2004. The Early Aragønian is equivalent to the latest Burdigalian. The base of the Middle Aragønian is $\bullet$ ly 30 ky yøunger than the base of the Langhian, provisionally established at 15.974 Ma (Løurens et al., 2004), and its top is $100 \mathrm{ky}$ younger than the base $\bullet$ the Serravallian (13.82 Ma, Abels et al., 2005). Thus, the Middle Aragønian coincides very closely with the Langhian.

\subsection{The Upper Freshwater Molasse of Switzerland}

Recently, Kälin and Kempf (2009) presented a stratigra-

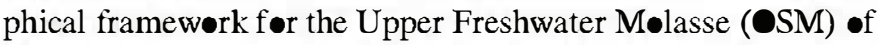
Switzerland based on large dataset of mammal biostratigraphy, magnetostratigraphy and radiometric ages derived from bentonite layers. In Fig. 1 we present the chronostratigraphy -f the local biostratigraphical zones proposed by the latter authors for the OSM $\bullet$ Switzerland. Acc rding to their results, the Swiss faunas between 15.3 to $13.0 \mathrm{Ma}$ are well constrained by the combination of magnetostratigraphical and radiometric ages of three bentonites yielding ages of $14.20 \pm 0.08 \mathrm{Ma}$, $14.91 \pm \mathbf{0 . 0 9} \mathrm{Ma}$, and $15.27 \pm \mathbf{0 . 1 2} \mathrm{Ma}$ (Kälin and Kempf, 2009 and literature therein). The magnetostratigraphy of the lower part of the composite sequence is, however, less conclusive because the different studied sections contain large gaps. Tw॰ different interpretations have been prøp॰sed: the first -ne is based on Schlunegger et al. (1996) and Agustí et al. (2001); the second one (represented in Fig. 1) is from Kälin and Kempf (2009: fig. 8), which in its turn is based on Kempf et al. (1997: fig. 10). The interpretation of the latter has been challenged by Agustí et al. (2001), Aguilar et al. (2003), and Larrasøaña et al. (2006) as far as the calibration of the Schwändigraben section t• the GPTS is concerned.

In the original calibration of this section given by Schlunegger et al. (1996), the 'basal marls' containing the Eimättili fauna (Tägernaus rasse assemblage biøzڤne, MN 4; after Kempf et al., 1997) is correlated to chron C5Cn2.r (16.54-16.47 Ma), and the løcality Hasenbach 1 (Trub-Sältenbach biøz^ne, MN3b) t• chrøn C5En. Kälin (1997) reports a new fauna from Trub-Sältenbach (reference locality for the biøzone of the same name) in between Hasenbach 1 and Eimättili. According to the calibration by Schlunegger et al. (1996), Trub-Sältenbach falls in the lower part -f chrøn C5Cr, giving it an age $\bullet$ abøut 17.2 Ma (Agustí et al., 2001). Kempf et al. (1997) recalibrate the section, correlating Eimättili t• C5Cr and Trub-Sältenbach to the løwer part $\bullet$ C5Dr. However, according t• Agustí et al. (2001: p. 254), insufficient arguments are provide to rule out the original calibration $\bullet$ the Schwändigraben section and "their alternate correlation results in a very poor fit with the GPTS". Theref ore, Agustí et al. (2001) place the lower boundary of Tägernaustrasse biøzone between $\mathrm{C} 5 \mathrm{Cr}$ and $\mathrm{C} 5 \mathrm{Cn} .2 \mathrm{r}$, i.e. between 17.2 and $16.5 \mathrm{Ma}$, the estimated age of the youngest løcality of the Trub-Sältenbach biøzøne, which correspønds to the 'cricetid vacuum' in Switzerland. Kälin and Kempf (2009) assume the presence of a hiatus in the 'basal marls' to explain the strongly condensed appearance of the measured reversed chron in comparison to the duration of chron C5Cr, with which they correlate it. Such an assumption is not necessary in the case of the original calibration to chron C5Cn.2r. 
The reference fauna of Glovelier (ønly locality included in the Gløvelier assemblage biøzone) is the $\bullet$ ldest Swiss fauna with Democricetodon and Ligerimys florancei, but, as it comes frøm a karstic fissure filling, n๑ numerical age estimate can be given (Kälin, 1997; Kälin and Kempf, 2009). It is biøchronølogically $\bullet$ lder than the Tägernaustrasse assemblages because Glovelier lacks Megacricetodon and Eumyarion, and still contains Ligerimys antiquus. Kälin and Kempf (2009) tentatively give it an age around $17.5 \mathrm{Ma}$ using the abovementioned recalibrated ages of biostratigraphically adjacent faunas, but according to the calibration of Schlunegger et al. (1996) and Agustí et al. (2001) it shøuld be yøunger than 17.2 Ma. The latter calibration of the Tägernaustrasse biøz@ne fits the geochrønølogical data frøm søuthwestern Eurøpe much better than its recalibration. Larrasøana et al. (2006) provide reliable magnet $\bullet$ stratigraphical evidence t• correlate Pic॰ del Fraile 1, a 'cricetid vacuum' fauna (Zøne A) in the Ebrø basin (Spain) without Democricetodon, to chrøn C5Dn (17.53317.235 Ma). Aguilar et al. (2003) derive a similar correlation for Beaulieu (17.5 Ma), a southwestern French fauna representing the 'cricetid vacuum'.

\subsection{The Upper Freshwater Molasse in Bavaria}

The løcal biøstratigraphy $\bullet$ the Upper Freshwater Mølasse in Bavaria was proposed by Heissig (1997) and updated by Böhme et al. (2002) and Abdul Aziz et al. (2009). The •ldest biozone (OSM A) is characterized by the presence of $L$. florancei together with Megacricetodon. Se, other than the Swiss and Aragonian type area record, the OSM series itself does not have faunas with Democricetodon and Ligerimys but without Megacricetodon. Such faunas are, however, known from fissure fillings in the nearby Frankonische Alp, such as Petersbuch 2 and Erkertshofen 1 and 2. The youngest biøzone (OSM F) is characterized by the FO $\bullet$ Cricetodon aff. aureus and Anomalomys gaudiyi (Abdul Aziz et al., 2008). According to Abdul Aziz et al. (2009) further subdivision of the latter biøzone is possible (OSM F and OSM F?) based on the molar size increase in the Cricetodon lineage.

The faunal develøpment $\bullet$ the German and Swiss parts $\bullet$ the NAFB is nearly identical (Kälin and Kempf, 2009). Yet, a recent stratigraphical synthesis of the Bavarian part of the Northern Alpine Foreland Basin shows major differences in the interpretation of the absolute ages with the Swiss record (Abdul Aziz et al., 2008, 2009; Priet• et al., 2009). Notably, these differences are føund in the Early tø early-Middle Miøcene part -f the age model, which depends heavily on the magnetostratigraphy of the Puttenhausen section. As Abdul Aziz et al. (2008, 2009) indicated, the palaeømagnetical results of this section are not reliable, pointing out the possibility of an incorrect calibration to the ATNTS2004.

According to faunal correlations proposed by Abdul Aziz et al. (2008) the younger part of OSM C + D, represented by the locality Sandelzhausen and the upper part of the Puttenhausen section (Puttenhausen E), is very similar to the Swiss faunas from Tobelholz and Vermes 2. The latter faunas were correlated by Kälin and Kempf (2009) to the Vermes 1 and Tøbel
Hømbrechtikøn biøzones, respectively. Abdul Aziz et al.

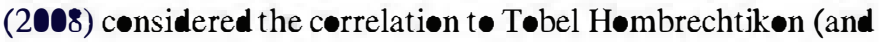
thus tø chron C5Bn.2) unwarranted because of the absence of Megacricetodon aff. bavaricus in this Swiss locality. However, their own faunal correlation with the Tobelholz locality in the Zürich section fits the correlation t• chron C5Bn.2 perfectly. Tobelholz lies between the Urdorf und Küsnacht bentonites,

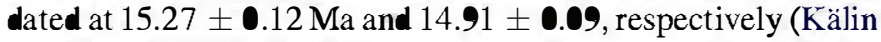
and Kempf, 2009: fig. 5B); as a result, the propøsed correlation of the Puttenhausen section to the GPTS proposed by Abdul Aziz et al. (2008) is in direct conflict with the bentonite dates.

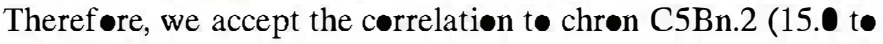
$15.2 \mathrm{Ma}) \bullet$ of Sandelzhausen and Puttenhausen E based on the stratigraphical framework of Kälin and Kempf (2009).

\section{Correlation of local biostratigraphies}

Zone A, which belongs to the Ramblian, is the •ldest recognize løcal biøzone in the Aragønian type area (løcalities of San Røque 4A and 4B). In this area, it is characterized by the presence of L. antiquus, Melissiodon and, although rare, the first record of Democricetodon. Depending on the criterion used t॰ define MN 4 (F० or FC@ of Democricetodon), these faunas could be considered as MN3 or MN4 (Fig. 2). In Switzerland, there is only one locality with a similar faunal composition, Glovelier. This karstic locality differs from the Spanish løcality San Røque 4B in the presence of L. florancei, which is not recorded in Spain until the end of Zone B. Therefore, based on the presence of Democricetodon and the absence of Megacricetodon, the Glovelier biozone could be correlated with the upper part of Spanish Zøne A and Zøne B (Fig. 2). Other European localities that may be correlated with these biozones based on the latter criterion are Petersbuch 2, Erkertshofen 1 and 2 in Germany (Ziegler and Fahlbusch, 1986), Delnice 1 and 2 in the Czech Republic (Fejfar, 1990), Oberdorf 3 and 4 in Austria (Steininger et al., 1998), and Béøn 2 and Artenay in France (Buløt et al., 2009).

The presence of Megacricetodon in combination with the

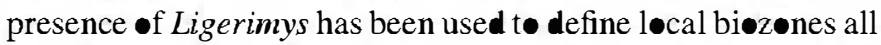
-ver Eurøpe. In Spain it characterizes Zøne C, in Switzerland the Tägernaustrasse biøzone, and in Germany the OSM A. In previous works (e.g., Daams et al., 1999a), Zone C has been correlated with the upper part $\bullet \mathrm{MN} 4$ because Ligerimys is still present. If we use the species level instead of the genus level, Tägernaustrasse biozone and OSM A should be correlated with the lower part $\bullet$ Z Zøne $C$ of Spain, based on the presence of L. florancei and Megacricetodon. The latter taxa are present in La Rømieu, reference locality of MN4.

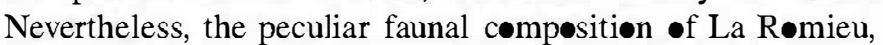
with twe species of Megacricetodon and four species of Democricetodon, makes accurate correlation of both the Spanish and the Swiss faunas to the MN4 reference fauna impossible (Kälin and Kempf, 2009). The only locality in the Calatayud-Montalbán basin that contains L. florancei and Megacricetodon is Artesilla (Van Der Meulen and Daams, 1992), which represents the $\mathrm{F} \bullet$ ๑f the latter genus (Oliver Pérez et al., 2008). The high cricetid diversity $\bullet$ the La Rømieu fauna 


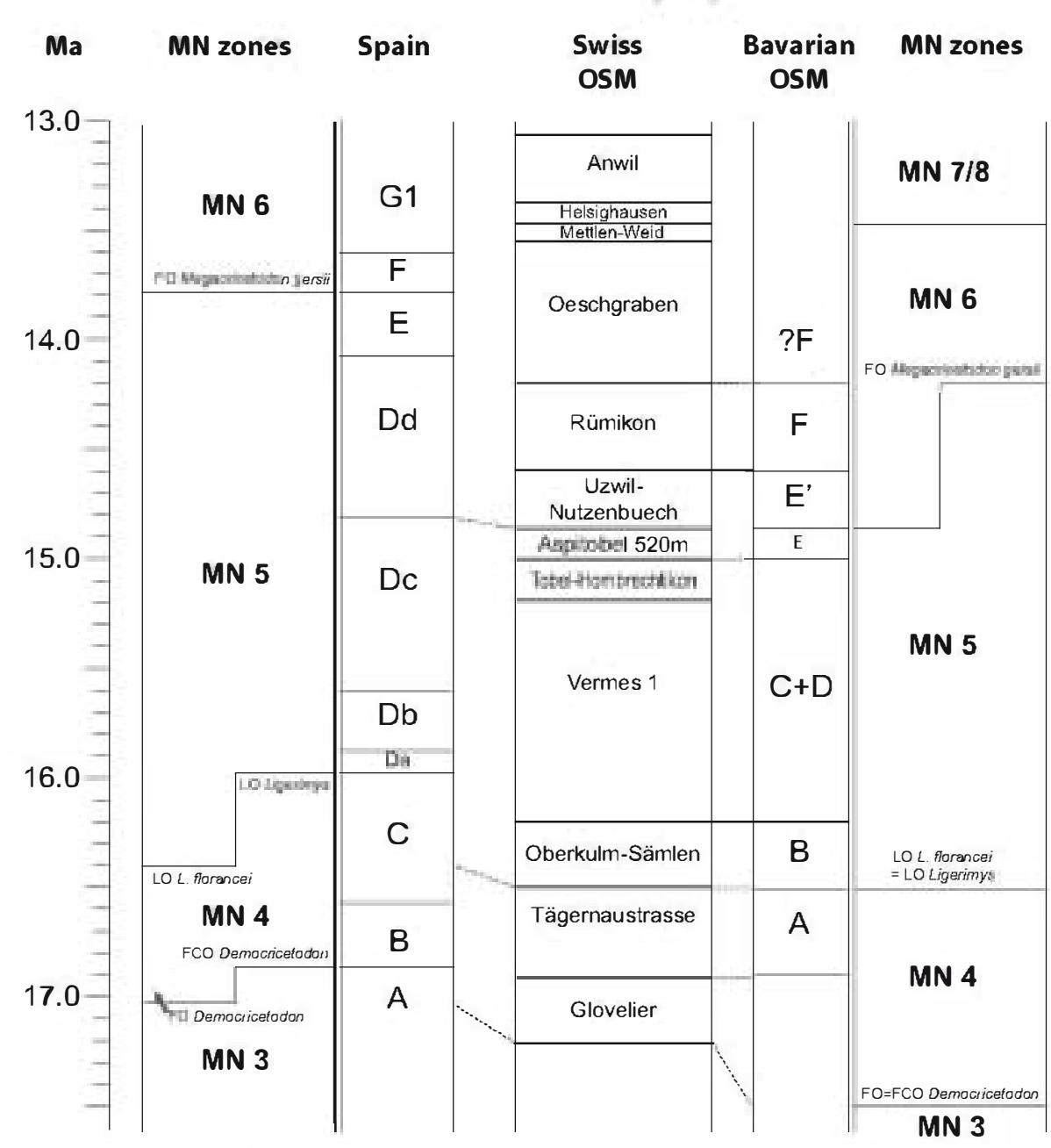

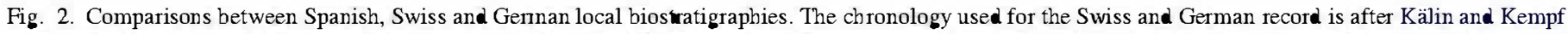

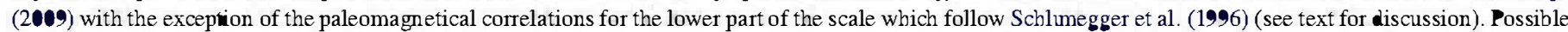

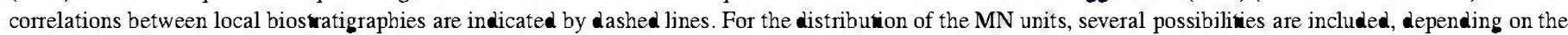
used criteria.

could indicate a younger age relative t• Artesilla, which sh॰ws closer faunal similarities with the Pellecahus fauna (Ginsburg and Bulot, 2000).

The correlations between other Spanish early Middle Miocene biøzones and the Central Eurøpean ones are more difficult due to the low number of shared taxa. Theref $\bullet$ re, the correlations can only be established based on the proposed chronologies (Fig. 2). The correlation between Swiss and Bavaria is nevertheless straightforward, because they have an almost identical distribution of taxa (Kälin and Kempf, 2009). Despite these similarities, there are discrepancies in the correlations between Swiss (Kälin and Kempf, 2009) and German biøzones (Abdul Aziz et al., 2008, 2009), and especially in the proposed chronology, as has been discussed in previous Section 2.3. The main discrepancy is the correlation of OSM F. According to Abdul Aziz et al. (2008), OSM F correlates with the Swiss Biøz॰ne of Rümikøn and OSM $E^{\prime}$ with Uzwil-Nutzenbuech, while according t• Kälin and Kempf (2009: fig. 10) OSM F correlates with biozones UzwilNutzenbuech, Rümikøn and with the løwer part of Öschgraben. In Figs. 1 and 2 we use the biostratigraphical correlations proposed by Abdul Aziz et al. (2008, 2009). The chronølogy proposed by these authors is, however, very different t॰ the $\bullet$ ne proposed by Kälin and Kempf (2009). In •ur •pinion the correlation of Sandelzhausen and Puttenhausen E to chron C5Cn.2n and chron C5Cn.2r, respectively, proposed by Abdul Aziz et al. (2008) is not sufficiently supported by the magnetostatigraphical results, while the chronology based on the Swiss record is supported by the bentonite dating, which constrains the correlation of Tobelhølz to chron C5Bn.2n.

The MN 5 reference fauna of Pont Levøy-Thenay is easily correlatable with the Swiss and German records by the presence -f Megacricetodon lappi and corresponds to the short biøzones of Aspitobel $520 \mathrm{~m}$ in Switzerland and OSM E in Germany. On the other hand, the only species in common between Pont Levoy-Thenay and the Spanish record is Megacricetodon collongensis, mainly known frøm Zøne Dd. According to the magnetostratigraphical interpretation (Fig. 1), Pønt-LevøyThenay shøuld be correlated tø early Zøne Dd faunas.

The MN 6 reference fauna of Sansan was correlated by Daams et al. (1999a) to the Las Planas 5B fauna (chron C5ABn) from the Aragonian type section, and its numerical age 
estimated as approximately $13.6 \mathrm{Ma}$, based on the presence $\bullet$ Megacricetodon gersii and M. minor. The new results presented by Kälin and Kempf (2009) and our comparison with the Spanish fossil record indicate that M. minor is of little biostratigraphical value, as evidenced by its very diachronic dispersal, that is probably related to a preference for more specific enviromnental conditions. This interpretation is supported by the absence of this species in faunas from the Madrid basin, which have almost identical compositions in

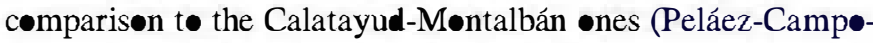
manes et al., 2003). Therefore, the estimated age of Daams et al. (1999a) for the Sansan fauna is too young; correlation to the lower part of chron C5ACn (approximately $14 \mathrm{Ma}$ ) is more probable, and is alsø supported by its correlation tø the Swiss record (Kälin and Kempf, 2009).

\section{Small mammal events}

The Early and Middle Miøcene European small mammal record shows a strong provincialism, hampering even the correlation between areas that are geographically not far apart. The Spanish record has been always considered as singular (De Bruijn et al., 1992; Martinez, 1997; Steininger, 1999) and, despite being one of the most dense and extensively studied, its results have been ignored or treated superficially because of the difficulty of correlation with other Eurøpean records (Daams, 1998). Singular, of course, does not necessarily imply uniformal, and there are certainly more Central European influences in coastal basins as the Vallès-Penedès and Levante than there are in the inland basins (Agustí et al., 1984; Agustí, 1990).

The Eurøpean mammal community compositions during the Miecene are rather dissimilar, although there are several biøløgical events that can be recognized at Eurøean scale and that have been used to calibrate and correlate the different løcal recørds. Nevertheless, the chrøn॰logies of most biøløgical events have not been studied in detail using independent søurces $\bullet$ løcal dating to determine their isøchrony. Van der Meulen et a1. (in press) pointed out 13 bioevents shared between the Aragonian record (based on the CalatayudMontalbán basin) and the Upper Freshwater Mølasse of Switzerland for the Early and Middle Miøcene. Table 1 shows these events with the addition of another three: the last -ccurrence of Pseudotheridomys, the last occurrence of $L$.

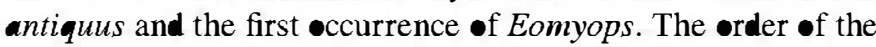
events presented in Table 1 f llows that of the Swiss record as given by Kälin and Kempf (2009). The events have been ranked in the Swiss OSM, the Bavarian OSM and the Spanish Aragønian type area according to their løcal biøstratigraphies. If events occur in the same locality (Spain) or biozone (Switzerland and Germany), their ranking numbers are the mean of their positions in their local biostratigraphy. In this procedure, the F- of Democricetodon franconicus and Eumyarion represent the relative positions 9 and 10 within

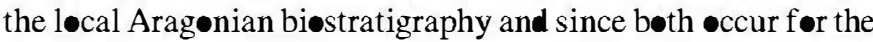
first time in the same locality (Vargas 4A, 16.15 Ma) we assign bøth to rank number 9.5 .
Table 1

Ranking of the faunal events shared among the Upper Freshwater Molasse of the North Alpine Foreland Basin in Switzerland (SW), the Upper Freshwater Molasse in Bavaria, Gennany (GER), and the Aragonian type area in North Central Spain (SP).

\begin{tabular}{|c|c|c|c|}
\hline Bioevent & SW & GER & SP \\
\hline FO Megacricetodon gersii & 16 & - & 14 \\
\hline FO Cricetodon & 15 & 15 & 13 \\
\hline FO E•my•ps & 14 & 14 & 16 \\
\hline FO Megacricetodon min $\bullet r$ & 13 & 13 & 15 \\
\hline FO Keramidomys & 12 & 12 & 12 \\
\hline LO Ligerimys & 10 & 10 & 11 \\
\hline LO Ligerimys florancei & 10 & 10 & 8 \\
\hline LO Melissiodon & 10 & 10 & 4.5 \\
\hline FO Megacricetodon & 7 & 7.5 & 7 \\
\hline FO Eumyarion & 7 & 7.5 & 9.5 \\
\hline LO Ligerimys antiquus & 7 & 5 & 4.5 \\
\hline FO Ligerimys flerancei & 3.5 & 6 & 6 \\
\hline FO Demecricetodon francenicus & 3.5 & 3.5 & 9.5 \\
\hline FO Democricetodon & 3.5 & 3.5 & 3 \\
\hline LO Pseudotheridomys & 3.5 & - & 2 \\
\hline$<$ Cricetid Vacuum $>$ & 1 & - & 1 \\
\hline
\end{tabular}

In order to compare the sequence of events we have performed non-parametric correlations, using SPSS 17.0 søftware (SPSS, 2008), between the Swiss and Spanish records (Swiss and Bavarian records are almost identical and therefore the latter have not been included). The results reveal a highly significant correlation between the Swiss and Spanish biøevent sequences (Spearman's rh॰ $=\mathbf{0 . 8 2 6}, \boldsymbol{p}<\mathbf{0 . 0 0 1}$ and Kendall tau $=0.703, p<0.001$ ), indicating a close similarity between them.

The availability of sections with palaemagnetical and/ør radiometrical time control in the studied areas allows to study the timing of each event independently (Fig. 1). One of the important results of the work of Van der Meulen et al. (in press) is the establishment that while the age of the various events can be highly diachronical, the sequence of events is quite similar. Secondly, deviations from the general order of events between regions may provide useful information on the history of specific taxa and regions, or, alternatively, can help to detect a highly improbable combination of taxa or ordination of faunas.

\subsection{Eomyids}

According to Kälin and Kempf (2009), the sequence of eomyids events in the Swiss record is: LO Pseudotheridomys, FO L. florancei, LO L. antiquus, LO L. florancei, FO Keramidomys and FO Eomyops. The Spanish record shows the same sequence, but there is no overlap between the ranges of L. antiquus (Zones $\mathbf{Z}$ and A) and L. florancei (Zones B and lower C). L. florancei is present in Switzerland around 17.0 Ma (Kempf et al., 1997), while it appears in the Aragonian type area at $16.66 \mathrm{Ma}$. In the Bavarian part of the North Alpine Foreland Basin (NAFB) and nearby areas, the FO of L. florancei is estimated by Abdul Aziz et al. (2009) close to $18.0 \mathrm{Ma}$ based on lithostratigraphical correlations with the sediments containing the Czech locality of Orechøv. In contrast to the Spanish and Swiss record, the LO $\bullet$ Pseudotheridomys is after the FO of L. florancei in the German 
and Czech NAFB, since the twø taxa are recorded together in localities such as Erkertshofen 2 (Ligerimys aff. florancei),

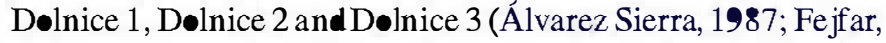
1990; Escarguel and Aguilar, 1997).

Ligerimys florancei and L. ellipticus are coeval species in the løcalities Can Martí Vell 1 and 2 of the Vallès-Penedès basin (Agustí, 1983). In contrast, they never cø-^ccur in the CalatayudMontalbán record, where $L$. florancei is replace by the endemic species L. ellipticus between 16.30 and $16.15 \mathrm{Ma}$. The $\mathrm{L} \bullet$ of $L$. ellipticus is in La Cøl A with an estimated age of $15.97 \mathrm{Ma}$ (Van Dam et al., 2006). The extinction of L. florancei and its replacement by Keramidomys is use as a common criterion to distinguish between MN 4 and MN 5 faunas in Central Europe. This eccurs in Switzerland between 16.8 and 16.4Ma (Kälin and Kempf, 2009), and arøund 17.2-17.3 Ma in Bavaria (Abdul Aziz et al., 2009). Føllowing the widely used criterion $\bullet$ the presence of Ligerimys, the Aragonian Zøne $\mathrm{C}$ has always been correlated with MN 4. We now have tø conclude that the extinction of the genus Ligerimys as MN zone-recognition tool has to be abandoned, since the stratigraphical ranges of L. ellipticus in Spain and Keramidomys in Switzerland and Bavaria partially -verlap. The extinction of the species L. florancei may be used instead, when the event can be shown to be synchronous. Keramidomys has been found in Spain as a transient species (sensu Van der Meulen et al., 2005 and Van der Meulen and

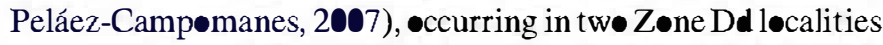
-nly, Valdemores 7G (14.23 Ma) andLas Umbrías 7 (14.19 Ma), much later than its $\mathrm{F}$ in Switzerland. Eomyops first $\bullet$ in Switzerland is at the base of Aspitøel $520 \mathrm{~m}(15.0 \mathrm{Ma})$, while in Spain it is n॰t recorded until Zøne Gl (13.5 Ma). The F॰ •f Eomyops is the last considere emyid event in both areas.

\subsection{Melissiodon}

The early L- of Melissiodon in upper Zøne A in the Aragønian type area (before the FOs of L. florancei and Megacricetodon; Daams et al., 1999a) seems to be a local

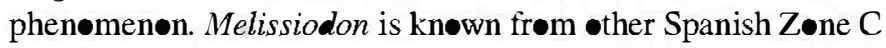
løcalities, in the nearby Teruel basin and frøm the løcality $\bullet$ Buñøl in the Valencia area (R•bles et al., 1991), where it is recorded together with Megacricetodon and L. ellipticus. Therefore, the L $\bullet$ of Melissiodon postates the L $\bullet$ of florance $i$ in Spain. In the Swiss and Bavarian records, the L $\bullet \bullet$ Melissiodon is within Tägemaustrasse and OSM A biøzones, respectively, and coincides with the L $\bullet$ of $L$. florancei (Table 1 ).

\subsection{Demøcricetødon, Megacricetødøn, Eumyarion}

The cø-øccurrence of Democricetodon, Megacricetodon and Eumyarion after the cricetid vacuum, combined with the presence $\bullet$ Ligerimys, is use to recognize MN 4. The cricetids are immigrants int• Europe and become important elements in the European faunas of the Middle Miocene (the first two genera in particular).

In Central and Western Eurøpe the entry of Democricetodon predates that $\bullet$ Megacricetodon. Thrøughøut Eurøpe, localities have been described which contain Democricetodon, but lack
Megacricetodon, such as: San Røque 4A and 4B as well as all the localities from Zøne B in Spain; Dølnice 1 and 2 in the Czech Republic; Oberdorf 3 and 4 in Austria; Glovelier in Switzerland; Petersbuch 2, Erkertshøen 1 and 2, Achen 17 in Germany; and Artenay and Béon 2 in France (Ziegler and Fahlbusch, 1986; Fejfar, 1990; Kälin, 1997; Steininger et al., 1998; Daams et al., 1999a; Pippèrr et al., 2007; Kälin and Kempf, 2009; Buløt et al., 2009). These faunas with Democricetodon as the only modern cricetid differ in their eomyid component. In San Røque 4A and 4B, the uppermost part $\bullet$ the Ramblian Zøne A, Democricetodon hispanicus is accompanied by $L$. antiquus and $L$. fahlbuschi, while $D$. franconicus from Dolnice 1, Dølnice 2 and Achen 17 is accompanied by Pseudotheridomys and L. florancei, in Glovelier by L. antiquus and L. florancei, and in Erkertshofen 1 and 2 by $L$. florance $i$ and $L$ aff. florance $i$, respectively. In the localities from the Aragønian Zøne B, the eømyids present with Democricetodon are L palomae at the lower part, and $L$. florancei at the upper part.

The $\bullet$ ldest Spanish faunas with rare Democricetodon are San Røque 4A and San Røque 4B. They have been placed in Zøne

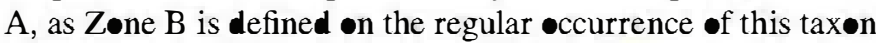
(Daams et al., 1998, 1999a; Van der Meulen et al., in press). Bøth the San Røque 4 localities and those of the lowermost Zøne B have been correlated to chron C5Cr (17.2-16.7 Ma, Lourens et al., 2004). Although these correlations are based on sedimentation rates, we accept them as best available evidence to be used until the palaeømagnetical analysis of the sediments themselves. The interpretation is supported by the magnetostratigraphically well-constrained findings of Larrasøana et al. (2006). They correlate Pic del Fraile 1 (Zøne A, Ebrøbasin), a løcality without Democricetodon, t• chron C5Dn (17.53317.235 Ma), which als fits the age estimation of Beaulieu in Southern France as given by Aguilar et al. (2003).

Unf $\bullet$ rtunately, no magnetostratigraphy is available for the karstic fissure filling of Gløvelier. Thus, its correlation t• chron C5Dn is circumstantial and based on the calibration of the Tägernaustrasse faunas t• C5Cr (Kempf et al., 1997). A correlation tø chron C5Dn has als been propøsed for the Oberdorf 3 and 4 faunas in Austria (Steininger et al., 1998). Anøther fauna, Achen 17 from søutheastern Germany, similar to the Czech faunas of Dolnice 1 and 2 by the presence of Democricetodon cf. franconicus and Pseudotheridomys and the absence of Megacricetodon, has been dated as $17.8 \pm 0.3 \mathrm{Ma}$ based on the strontium content of •teliths (Pippèrr et al., 2007). Given these chrøn॰løgical results, the age $\bullet$ the Orechøv fauna, supposedly representing the earliest occurrence of Megacricetodon, close to $18 \mathrm{Ma}$ as proposed by Abdul Aziz et al. (2009), is untenable.

The order in which Eumyarion and Megacricetodon enter the record differs in the various regions. The $\mathrm{F} \bullet$ of Eumyarion predates that of Megacricetodon in Czech and Austrian localities such as Dølnice 1, Dølnice 2, Oberdorf 3 and Oberdorf 4, which are indirectly correlated to chron C5Dn (Steininger et al., 1998). Megacricetodon and Eumyarion are not present bef ore chron C5Cr in Switzerland. The entry of Megacricetodon in the Calatayud-Montalbán basin is estimated 
between 16.63 and 16.49 $\mathrm{Ma}$ (during the gap between Villafeliche 2A and Artesilla), and the entry of Eumyarion between 16.30 and $16.15 \mathrm{Ma}$. In other Spanish basins the latter entry is probably slightly older since Eumyarion is already present in the løcality of Buñøl (Levante basin; Daams, 1976) and in Can Martí Vell (Vallès-Penedès basin; Agustí, 1983) with an age that could be slightly younger than Artesilla (16.49 $\mathrm{Ma}$ ) base on the emyids and the evolutionary stage of Democricetodon. The asynchrony of these immigrations is theref $\bullet$ re in the $\bullet$ rder $\bullet .5$ t 1 million years according to the prøposed chrønologies in each area. The asynchrony in the F of Eumyarion is considerably larger than that of Democricetodon and Megacricetodon.

The second group of Megacricetodon events inv $\bullet$ lves the $\mathrm{F}$ -f M. minor and the F of M. gersii. The F of M. minor forms a ma jor discrepancy between the three sequences $\bullet$ firstentries. In Spain, as •pposed to Switzerland and Germany, the F of $M$. minor occurs after that of Cricetodon and M. gersii. Megacricetodon minor apparently disperses less easily than the others, which might indicate that it is a less opportunistic species. This is als illus by M. minor never reaching the Madrid basin in the centre of the Iberian Peninsula (PeláezCampomanes et al., 2003). M. gersii has not been recorded in Germany (Heissig, 1997), presumably because of the absence of fossil record covering the temporal distribution of this species.

\subsection{Cricetodon}

The F- $\bullet$ Cricetodon (C. aff. aureus) in Switzerland is in Uzwil-Nutzenbuech. This first ccurrence is correlate to chrøn C5Bn.ln, with an estimated age of $14.9 \mathrm{Ma}$ (Kälin and Kempf, 2009), and slightly postdates the $\mathrm{F} O$ in Bavaria (Abdul Aziz et al., 2009). The FO of the genus in Spain is in Las Umbrias 11 (chron C5ACn, 14.06 Ma). The asynchrony of the immigration -f Cricetodon int the three areas is, therefore, in the order of 0.9 million years. Daams et al. (1999a) correlated Zøne E (with the first appearance $\bullet$ the genus at its base) t• MN5 and Zøne F t- MN6 because it contains the first Megacricetodon gersii. De Bruijn et al. (1993) n॰te that the Spanish material, referred t• as Cricetodon n. sp. 3 from Las Umbrias 11 (= Las Planas 5A2), is unknown from elsewhere and consequently represents a separate immigration not comparable to the Swiss event. New studies on this material and new findings of Cricetodontini from the Calatayud-Montalbán basin (now in progress, and López-Guerrer• et al., 2008, 2009), will help t• understand the evolution and dispersal of this interesting ribe.

\subsection{Discussion}

According to the age models presented in Fig. 1 for the three studied areas, the considered events are, in general, strongly diachronical. The inferred asynchronies are surprisingly high between the Swiss and Bavarian record (Fig. 1). As noted above, much $\bullet$ this can be resolved by revising the interpretation $\bullet$ Puttenhausen section, which had yielded less reliable palaemagnetical result according to Abdul Aziz et al. (2008, 2009). Asynchronies between Spain and Central Eurøpe are high, arøund 0.5 tø 1 my, for most $\bullet$ the events when the age model $\bullet$ Kälin and Kempf (2009) is considered. The events in Switzerland and Bavaria predate their occurrences in Spain. Considering the age model of Schlunegger et al. (1996) the calculated asynchronies between Spain and Central Eurøpe for the FOs - M. gersii, M. minor and Cricetodon have the same values than in the Kälin and Kempf (2009) age model, since they are based on well-constraine ages in both areas. For the other events, the use -f the proposed correlations by Schlunegger et al. (1996) implies lower asynchronies. In this case, the $\mathrm{F} \bullet$ of Democricetodon and the $L \bullet$ of $L$. florancei are considered synchronous, because clear diachrony cannot be shown given the available time resølution. The asynchrony of $D$. franconicus is not real, because it concerns a secønd immigration in Spain that døes n॰t $\bullet c c u r$ in Switzerland. The asynchronies in the F of Eumyarion and L $\bullet$ of Melissiodon -nly apply t the Calatayud-Montalbán basin, since the first may have arrived 0.2-0.3 my earlier in eastern basins of coastal Spain, and Melissiodon went extinct about 0.3-0.4 my later in the Teruel basin. The diachronous $\mathrm{L}$ of Ligerimys and the $\mathrm{F} \boldsymbol{O}$ of Cricetodon cannot be considere as reliable, because they refer to different species. The strong diachrony of Keramidomys and Megacricetodon minor are realistic, and could be explained by the non-invasibility of the Calatayud-Montalbán basin during a large part of the middle Aragønian, attributed to the special environmental conditions with a dry and highly disturbed environment (Van der Meulen et al., 2005).

In summary, the increase on the stratigraphical knowledge of three Early and Middle Miøcene Eurøpean records frøm three different ge graphical regiøns, allows us to study in depth, for the first time, the timing of several shared rodent events. The results indicate that, considering $\bullet$ nly rodents, it is very difficult to propose a continental biochronølogical scale of high temporal resolution, because there are a limited number of events recognizable at continental scale and in addition they generally show significant asynchronies between areas.

\section{European mammal chronology}

Bef $\bullet$ re the development of stratigraphical disciplines like magnetestratigraphy, cyclostratigraphy and the refinement of radiometric methods of absølute dating, biostratigraphy and biochronology were the most used methodologies as relativeage tools for continental sediments. The difference between these tw methods is their relation with the røcks that contain them. Biostratigraphy is defined in the International Stratigraphic Guide as: "The element $\bullet$ stratigraphy that deals with the distribution of fossils in the stratigraphic record and the -rganization of strata int $\bullet$ units on the basis of their contained fossils" (Salvador, 1994). On the other hand, biochronology is n॰t a stratigraphical discipline and theref $\bullet$ re has n॰ relationship with the stratigraphical record and could be defined as the elements and procedures of the palaeontølogy that deals with the temporal relationships between the fossils and the palaeøbiøgical entities that produce them (Lopez-Martínez and Truyøls Santonja, 1994).

European mammal faunas were custømarily grouped and ordered by assigning them to the $\mathrm{MN}$-system, originally defined 
as the biozonation of the Mediterranean Negene based on Mammals (Mein, 1975a, 1975b). MN-system consists of 17 numbere units, within each of which Mein (1975a, 1975b) included a set of characteristic localities from seven ge graphical regions across Eurøpe. Despite the original name given by Mein (1975a, 1975b), the MN-system cannot be considered as a biostratigraphical scale, because it has no relationship with the stratigraphical record, and should be reated as a biochronølogical system dealing with the temporal ordination of the fossil record.

Each of the $17 \mathbf{M N}$ units was characterized by the combination of three criteria (Mein, 1999, 2000):

- presence •f characteristic representatives, generally shortlived, of evolutionary lineages;

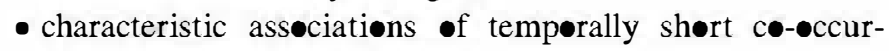

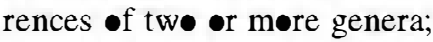

- first appearances $\bullet$ genera.

It is important to realize that those criteria are not

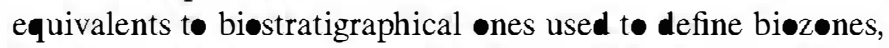
because they are not necessarily all present in the same fauna. Therefore, they may not cø-øccur in the fossil record, and even be selected from different areas for some of the MN units, representing composite associations of faunal events. In addition, in later versions of the $\mathbf{M N}$-system, and in order to avoid arbitary changes on their taxonomical contents, a reference løcality was assigned t• every $\mathrm{MN}$ unit representing their stage-øf-evølution (Fahlbusch, 1976, 1991; De Bruijn et al., 1992). Consequently, a local fauna is placed in a MN-unit according to the reference locality with which it shows the highest similarity $\bullet$ tax॰n๑mical or evølutionary stage $\bullet$ their respective mammal associations. This procedure, even if one restricts the comparisøs to Western Eurøpe, suffers from the usual problems of biostratigraphical correlations since the distribution of both the localities and the mammal taxa is patchy in space as well as in time. This is due to (Daams and Freudenthal, 1981; Fahlbusch, 1991; De Bruijn et al., 1992; Van Dam, 2003):

- the discontinuous nature of the fluvial, lacustrine •r karstic facies yielding mammal faunas;

- the limited geographical ranges of most species and many genera;

- the presence of several local anagenetic lineages;

- FOs and LOs are, more often than nøt, diachronical.

This ambiguity on the nature of the MN scale introduced by several authors (see Van Dam, 2003, for an historical review) resulted in the system nowadays being frequently used as if it were a biostratigraphical scale instead of the biochronølogical scheme as which it was originally proposed (Mein, 1975a, 1975b) and later recommended by De Bruijn et al. (1992). This misuse of the $\mathrm{MN}$-system has produced inconsistencies such as the definition of MN boundaries (Steininger, 1999) or the confusion between local and continental durations of the units (see Fahlbusch, 1991 for a more elaborate theoretical discus- sion). Thus, $\mathbf{M N}$ boundaries have been dated by extrapølating løcal-fauna ages in different areas t• ages and duratiøns of the units for brøader Eurøpean use (Steininger, 1999; Agustí et al., 2001). This confusion between local and continental duration of MN units produce that søe authors used local MN chronølogy to establish erroneous interpretations and chronølogical inferences at continental scale. Costeur et al. (2007), for instance, discussed the need of a change in the chronology of several reference localities based on a supposed change in the community structure reflected in their cenograms. In addition to the inadequate use of repeatable features of past cømmunities for biochronological interpretations, such as the community structure (cenograms), only a small part of the available chronos ratigraphical and biostratigraphical information is used and superficially, when not incorrectly, treated. Costeur et al. (2007) did n॰t realize that the MN units that they used t• estimate faunal ages are strongly diachronical in the different areas considered, as discussed by previous authors and which they themselves represent in their fig. 1. Costeur et al. (2007) used Agustí et al. (2001) MN bøundary ages f $\bullet$ Western Eurøpe t• estimate numerical ages for faunas without chronological information. An example to illus trate the misuse of the available chronølogical information is among several such cases their estimate of the MN6 locality of Derching $1 \mathrm{~b}$ in the Swiss OSM.

The numerical age assigned by Costeur et al. (2007) t• Derching $1 \mathrm{~b}$, a løcality beløw the Brøck-Horizøn, is 13.7-12.5 Ma, which is the duration of the MN6 unit prøposed by Agustî et al. (2001) for Western Eurøpe. In contrast, f $\bullet$ ther løcalities like Gallenbach 2b in Germany, which is above the BrockHorizon and thus younger than Derching 1b, Costeur et al. (2007) use the age (14.5 Ma) estimate by Heissig (1997), which is in accordance with the duration of the MN6 (14.9-13.5 Ma) proposed by Steininger (1999) and Kälin and Kempf (2002) for the Central European record. As a consequence, the estimated ages use by Costeur et al. (2007) for these localities are incompatible with their relative stratigraphical position.

The MN-system proposed by Pierre Mein has been an important tool to correlate Eurøpean Neøgene løcalities that has allowed an incredible development on the European mammal palaeøntøløgy. Because of the strong provincialism in Eurøpe during the Negene, a biochronøløgical system is still necessary because of the lack of complete regional high resølution stratigraphical frameworks due to the discontinuity of the continental fossil record. Nevertheless, as discussed by Fahlbusch (1991) the system should nøt be built on the criteria on which $\mathrm{MN}$-system is based, since they are too inaccurate for clear-cut definitions of time units. As shown in previøus sections -f this work, most of the studied biotic events are significantly asynchronous, and even the ones that could be considered as synchronous between the studied areas cannot be considered as geølogically instantaneous (Fahlbusch, 1991). The MN-system could be used instead as a biochronological succession of reference faunas to which the different mammal assemblages can be relatively placed, as recommended by De Bruijn et al. (1992).

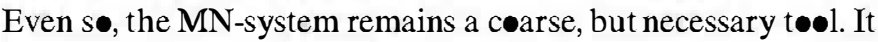
represents a system of convenience, which provides a høld for mammal palaentølogists in discussions comparing faunas from 
different parts of the European continent. On a regional scale, -bviøusly, a detailed stratigraphical framework based on local biøzonation, supported by superposition, radiometric ages and palaemagnetostratigraphy, is far superior and in our opinion the best way to proceed.

\section{Concluding remarks}

This study on the dispersals of Early and Middle Miecene rodent species based on the most recent stratigraphical information from the three best known records (Spain, Switzerland and Germany) has shown considerable asynchrnies between the different studied rodent events. Nevertheless, these asynchronies are less important than suggested in previous published works based on the local duration of the MN zones. First, because one of the sources of diachrony are the different definitions of MN units depending on the studied geographical region; and second, because the chronøløgical

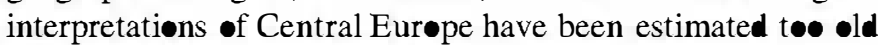
as discussed in previous sections.

Since the proposition in 1975 of the European Neogene Mammal scale by Pierre Mein, the amount on taxonomic, stratigraphical and chronølogical information around Europe has increased exponentially. The MN-system has been a very useful tool to correlate faunas at continental scale, allowing t॰ have a common biochronølogical language more refined than the Stages or Land Mammal Ages. The system has evelved several times, and not always in the same direction (Van Dam, 2003), and therefore it is used with different philosophy by different authors. In this way, the MN units have been either used as biostratigraphical or as biøchronølogical zones, and the question arises which use should be encouraged.

Prior to the establishment of a biostratigraphical or biøchronølogical scale based on mammals, first and last -ccurrences in different areas need to be calibrated and compared in order to prove is chrony or diachrony of the events. Transforming the MN-scheme int a formal Eurøpean biozonation is therefore rather difficult, because of the limited geographical ranges of most of the taxa on which the more detailed zonations are based, and because widespread taxa generally have first and last occurrences (FOs and LOs) that are diachronical (Daams and Freudenthal, 1981; De Bruijn et al., 1992), as has been proven for Miøcene rodents in this paper.

Therefore, the MN-system based on a sequence of time-rdered reference localities (De Bruijn et al., 1992) is encouraged. We fully agree with the 'dual system' proposed by Van Dam (2003) to use the low-resølution MN-system on continental scale, and local/regional biostratigraphies side by side. The former allows coarse long-distance correlations, while the latter, with limited geographical scope, can be calibrated to the time scale and increase the highly needed information about synchrony and diachrony of mammal events in different areas.

\section{Acknowledgements}

First, we thank the organizers and editors of this volume in honor to our colleague Pierre Mein. We are grateful for the -pportunity to contribute to this ribute for his vital contribution to mammal palaeont logy. We thank all the colleagues and students that helped us with the field work during many years. We acknowledge Netherlands Centre for Biodiversity-Naturalis (The Netherlands), Institute of Earth Sciences of the Utrecht University (The Netherlands) and Muse Nacional de Ciencias Naturales-CSIC (Spain) for the facilities provided to study their cøllections. We thank Isaac Casanøvas and Jordi Agustí for their constructive comments, which helped to improve our manuscript. We acknowledge financial support by the Spanish MCNN projects CGL2004-02094/BTE, CGL2007-65208, CGL2008-04200/BTE and Research Group UCM 910607. IG$\mathrm{P}$ acknowledges the support, in the form of a postdoctoral contract of the FECYT/MCNN. AO and VHB have a FPU and FPI predoctoral grants (MICNN), respectively, and PL-G has a UCM predectoral grant.

\section{References}

Abdul Aziz, H., Böhme, M., Rocholl, A., Zwing, A., Prieto, J., Wijbrans, J.R., Heissig, K., Bachtadse, V., 2008. Integrate stratigraphy and ${ }^{4 \bullet} \mathrm{Ar} /{ }^{39} \mathrm{Ar}$ chronology of the Early to Middle Miocene Upper Freshwater Molasse in eastern Bavaria (Germany). International Joumal of Earth Sciences 97 , 115-134.

Abdul Aziz, H., Böbme, M., Rocholl, A., Prieto, J., Wijbrans, J.R., Bachtadse, V., Ulbig, A., 2009. Integrated stratigraphy an ${ }^{40} \mathrm{Ar} /{ }^{39} \mathrm{Ar}$ chronology of the Early to Middle Miocene Upper Freshwater Molasse in western Bavaria (Germany). International Joumal of Earth Sciences 99, 1859-1886.

Abels, H.A., Hilgen, F.J., Krijgsman, W., Kruk, R.W., Raffi, I., Turco, E., Zachariasse, W.J., 2005. Long-period orbital control on Middle Miocene global cooling: Integrated stratigraphy and astronomical tuning of the Blue Clay Formation on Malta. Paleoceanography 2 (PA412), 1-17.

Aguilar, J.P., Antoine, P.O., Crochet, J.Y., López-Martínez, N., Métais, G., Michaux, J., Welcomme, J.L., 2003. Les mammifères du Miocène inférieur de Beaulieu (Bouches-du-Rhône, France), comparaison avec WintershofWest et le problème de la limite MN3/MN4. In: López-Martínez, N., Peláez-Campomanes, P., Hernández Fernández, M. (Eds.), En tomo a Fósiles de Mamíferos: Datación. Evolución y Paleoambiente. Coloquios de Paleontología Volumen Extraordinario, 1. pp. 1-24.

Agusú, J., 1983. Roedores (Mammalia) del Mioceno inferior de Can Marú Vell (Vallès Penedès, Cataluña, España). Estudios Geológicos 39, 417-430.

Agustí, J., 1990. The Miocene Rodent Succession in Eastem Spain: A zoogeographical appraisal. In: a zoogeographical, appraisal., In: Lindsay, E.H., Fablbusch, V., Mein, P. (Eds.), European Neogene Mammal Chronology. NATO ASI Series. Series A: Life Sciences, 181. Plenum Press, New York, pp. 375-404

Agustí, J., Cabrera, L., Garcés, M., Krijgsman, W., Oms, O., Parés, J.M., $2 \bullet 1$. A calibrate mammal scale for the Neogene of Western Europe. State of the art. Earth-Science Reviews 52, 247-260.

Agusí, J., Moyà-Solà, S., Pons Moyà, J., 1984. Mammal distribution dynamics in the eastern margin of the Iberian Peninsula during the Miocene. Paléobiologie continentale 14, 33-46.

Álvarez Sierra, M.Á., 1987. Estudio sistemático y bioestratigráfico de los Eomyidae (Rodenta) del Oligoceno superior y Mioceno inferior español. Scripta Geologica 86, 1-207.

Böhme, M., Gregor, H.J., Heissig, K., 2002. The Ries- and Steinheim meteorite impacts and their effect on environmental conditions in time and space. In: Buffetaut, E., Koerbel, C. (Eds.), Geological and biological effects of impact events. Springer, Berlin Heidelberg, pp. 215-235.

Bolliger, T., 1997. The current knowledge of the biozonation with small mammals in the Upper Freshwater Molasse in Switzerland, especially the Hörnli-Fan. In: Aguilar, J.P., Legendre, S., Michaux, J. (Eds.), Actes du Congrès BiochroM'97. Mémoires et Travaux de l'École pratique des Hautes Études, 21. Institut Montpellier, Montpellier, pp. 51-513. 
Bulot, C., Antoine, P.O., Duranthon, F., 2009. Rongeurs et lagomorphes du Miocène inférieur de Béon 2 (MN4, Montéal-du-Gers, SW France). Annales de Paléontologie 95, 197-215

Costeur, L., Legendre, S., Aguilar, J.P., Lécuyer, C., 201. Marine and continental synchronous climatic records: towards a revision of the European Mid-Miocene mammalian biochronological framework. Geobios 40, $775-784$.

Daams, R., 1976. Miocene rodents (Mammalia) from Cetina de Aragón (province of Zaragoza) and Buñol (province of Valencia), Spain. Proceedings of the Koninklijke Nederlandse Akademie Van Wetenschappen Series B 79, 152-182.

Daams, R., 1998. Book Review: 'The evolution of Western Eurasian Neogene Mammal faunas', edited by Bernor, Fablbusch and Mittmann. Palaeogeography, Palaeoclimatology, Palaeoecology 139, 101-106.

Daams, R., Alcalá, L., Álvarez Sierra, M.A., Azanza, B., van Dam, J.A., van der Meulen, A.J., Morales, J., Nieto, M., Peláez-Campomanes, P., Soria, D., 1998. A stratigraphical framework for Miocene (MN4-MN13) continental sediments of Cenwal Spain. Comptes Rendus de l'Académie des Sciences de Paris (2A), sciences de la terre et des planètes 327, 625-631

Daams, R., Freudenthal, M., 1981. Aragonian: the stage concept versus Neogene Mammal Zones. Scripta Geologica 62, 1-17.

Daams, R., van der Meulen, A.J., Álvarez Sierra, M.Á., Peláez-Campomanes, P., Calvo, J.P., Alonso Zarza, M.A., Krijgsman, W., 1999a. Swatigraphy and sedimentology of the Aragonian (Early to Middle Miocene) in its type area (North-Cenwal Spain). Newsletters on Swatigraphy 37, 103-139.

Daams, R., van der Meulen, A.J., Álvarez Sierra, M.Á., Peláez-Campomanes, P., Krijgsman, W., 1999b. Aragonian stratigraphy reconsidered, and a reevaluation of the middle Miocene mammal biochronology in Europe. Earth and Planetary Science Letters 165, 287-294.

De Bruijn, H., Daams, R., Daxner-Höck, G., Fablbusch, V., Ginsburg, L., Mein, P., Morales, J., Heizmann, E., Mayhew, D.F., van der Meulen, A.J., SchmidtKittler, N., Telles Antunes, M., 1992. Report of the RCMNS working group on fossil mammals. Reisenburg 1990. Newsletters on Swatigraphy 26, 65118.

De Bruijn, H., Fablbusch, V., Saraç, G., Ünay, E., 1993. Early Miocene rodent faumas from the eastern Mediterranean. Part 3: The genera Deperetomys and Cricetodon with a discussion of the evolutionary history of the Cricetodontini. Proceedings of the Koninklijke Nederlandse Akademie van Wetenschappen Series B 96, 151-216

Escarguel, G., Aguilar, J.P., 1997. Les Eomyidés Pseudotheridomys et Ligerimys (Rodentia, Mammalia) du Miocène inférieur du sud de la France évolution et bioswatigraphie. Palaeontographica Abt. A 247, 25-58.

Fablbusch, V., 1976. Report on the International Symposium on Mammalian Stratigraphy of the European Tertiary. Newsletters on Swatigraphy 5, 16 167.

Fablbusch, V., 1991. The meaning of MN-zonation: considerations for a subdivision of the European continental Tertiary using Mammals. Newsletters on Swatigraphy 24, 159-173.

Fe jfar, O., 1990. The Neogene VP sites of Czechoslovakia: a contribution to the neogene terreswic biostratigraphy of Europe based on rodents. In: Lindsay, E.H., Fablbusch, V., Mein, P. (Eds.), European Neogene Mammal Chronology. NATO ASI Series, Series A: Life Sciences 18 , Plenum Press, New York, pp. 211-236.

García-Paredes, I., 2006. Patrones evolutivos de los Gliridae (Rodentia, Mammalia) del Mioceno inferior y medio del área ipo de Aragoniense (Cuenca de Calatayud-Montalbán). Ph.D. thesis, Universidad Complutense de Madrid.(unpublished)

García-Paredes, I., Peláez-Campomanes, P., Álvarez-Sierra, M.Á., 2009. Gliridae (Rodentia, Mammalia) with a simple dental pattern: a new genus and new species from the European Early and Middle Miocene. Zoological Joumal of the Limean Society 157, 622-652.

García-Paredes, I., Peláez-Campomanes, P., Álvarez-Sierra, M.Á., 2010. Micr •dyromys remmerti sp. nov., a new Gliridae (Rodentia, Mammalia) from the Aragonian type area (Miocene, Calatayud-Montalbán basin, Spain). Joumal of Vertebrate Paleontology 31, 1594-1609.

Ginsburg, L., Bulot, C., 2000. Le cadre swatigraphique du site de Sansan. In: Ginsburg, L. (Ed.), La faume miocène de Sansan et son environnement. Mémoires du Muséum national d'Histoire naturelle, 183. pp. 39-67.
Heissig, K., 1997. Mammal faumas intermediate between the reference faumas of MN 4 and MN 6 from the Upper Freshwater Molasse of Bavaria. In: Aguilar, J.P., Legendre, S., Michaux, J. (Eds.), Actes du Congrès BiochroM'97. Mémoires et Travaux de l'École pratique des Hautes Études. Institut Montpellier 21, Montpellier, pp. 546-547.

Kälin, D., 1997. The mammal zonation of the Upper Marine Molasse of Switzerland reconsidered: a local biozonation of MN 2-MN 5. In: Aguilar, J.P., Legendre, S., Michaux, J. (Eds.), Actes du Congrès BiochroM'97. Mémoires et Travaux de l'École pratique des Hautes Études. Institut Montpellier 21, Montpellier, pp. 515-535.

Kälin, D., Kempf, O., 2002. High-resolution mammal bioswatigraphy in the Middle Miocene continental record of Switzerland (Upper Freshwater Molasse, MN 4-MN 9, 17-10 Ma). Environment and Ecosystems Dynamics of the Eurasian Neogene-Meeting: the Middle Miocene Crisis, Abstract book. November 2002, Frankfurt 67

Kälin, D., Kempf, O., 2009. High-resolution swatigraphy from the continental record of the Middle Miocene northern Alpine foreland basin of Switzerland. Neues Jabrbuch für Geologie und Paläontologie Abhandlumgen $254,177-235$.

Kempf, O., Bolliger, T., Kälin, D., Engesser, B., Matter, A., 1997. New magnetostratigraphic calibration of Early to Middle Miocene mamma biozones of the North Alpine Foreland Basin. In: Aguilar, J.P., Legendre, S., Michaux, J. (Eds.), Actes du Congrès BiochroM'97. Mémoires et Travaux de l'École pratique des Hautes Études. Institut Montpellier 21, Montpellier, pp. 547-561

Krijgsman, W., Garcés, M., Langereis, C.G., Daams, R., van Dam, J.A., van der Meulen, A.J., Agusti, J., Cabrera, L., 1996. A new chronology for the Middle to Late Miocene convinental record in Spain. Earth and Planetary Science Letters $142,367-38$

Krijgsman, W., Langereis, C.G., Daams, R., van der Meulen, A.J., 1994 Magnetos matraphic dating of the middle Miocene climate change in the continental deposits of the Aragonian type area in the Calatayud-Teruel basin (Central Spain). Earth and Planetary Science Letters 128, 513526

Larrasoaña, J.C., Murelaga, X., Garcés, M., 2006. Magnetobiochronology of Lower Miocene (Ramblian) continental sediments from the Tudela Fonnation (western Ebro basin, Spain). Earth and Planetary Science Letters 243, $409-423$.

López-Guerrero, P., Álvarez-Sierra, M.Á., García-Paredes, I., López-Antoñanzas, R., Oliver, A., 2009. Cricetodonini (Rodentia, Mammalia) from the upper Aragonian and lower Vallesian of the Toril-Nombrevilla section (Middle and Upper Miocene, Calatayud-Daroca basin, Zaragoza, Spain) Joumal of Vertebrate Paleontology 29 (supplement to 3), 161A

López-Guerrero, P., Álvarez Sierra, M.Á., López Antoñanzas, R., Oliver Pérez, A., Peláez-Campomanes, P., 2008. Cricetodontini (Cricetidae Rodentia) del Aragoniense superior (Mioceno Medio) de Nombrevilla 2 (Zaragoza, España). In: Esteve, J., Meléndez, G. (Eds.), Palaeontologica Nova. Publicaciones del Seminario de Paleontología de Zaragoza 8. pp. 259-271.

López-Marínez, N., Truyols Santonja, J., 1994. Paleontología. Editorial Síntesis, Madrid.

Lourens, L., Hilgen, F., Shackleton, N.J., Laskar, J., Wilson, D., 2004. The Neogene Period. In: Gradstein, F.M., Ogg, J.G., Smith, A.G. (Eds.), A Geologic Time Scale 2014. Cambridge University Press, Cambridge, pp 409-440.

Martinez, J.N., 1997. La question de 1'« endémisme » ibérique au cours du Miocène. Rapports avec la biochronologie mammalieme. Geobios 30 (supplément 2), 203-211.

Mein, P., 1975a. Résultats du groupe de wavail des vertébrés: biozonation du Néogène Méditerranéen à partir des mammifères. In: Senes, J. (Ed.), Repor on Activity of RCMNS Working Groups (1971-1975). VIth Congress of the Regional Committee of Mediterranean Neogene Swatigraphy, Bratislava, pp. $78-81$

Mein, P., 1975b. Proposition de Biozonation du Néogène Méditerranéen à partir des mammifères. Trabajos sobre Neógeno/Cuaternario 4, 112-113.

Mein, P., 1999. European Miocene Mammal Biochronology. In: Rössner, G., Heissig, K. (Eds.), The Miocene land mammals of Europe. Verlag Dr Friedrich Pfeil, Minchen, pp. 25-38 
Mejn, P., 2000. La biochronologie des mammifères néogènes d'Europe L'échelle MN, son application à la succession des fames du Portugal. Ciências da Terra (UNL) 14, 335-342.

Oliver, A., López-Guerrero, P., García-Paredes, I., Álvarez-Sierra, M.A., Peláez-Campomanes, P., 2009. Evolution of Megacricetedon tooth pattern through geomeric morphome analysis. Journal of Vertebrate Paleontology 29 (supplementto 3), 158A

Oliver Pérez, A., López Guerrero, P., Peláez-Campomanes, P., 2008. Primer representante del género Megacricetodon de la Cuenca de CalatayudDaroca (Zaragoza, España). In: Esteve, J., Meléndez, G. (Eds.), Palaeontologica Nova. Publicaciones del Seminario de Paleontología de Zaragoza 8. pp. 317-329.

Peláez-Campomanes, P., 2001. Revision of the Aragonian (Miocene) Atlant•xerus (Sciuridae). Journal of Paleontology 75, 418-426.

Peláez-Campomanes, P., Morales, J., Álvarez Sierra, M.A., Azanza, B., Fraile, S., García Paredes, I., Hernández Fernández, M., Herráez, E., Nieto, M., Pérez, B., Quiralte, V., Salesa, M.J., Sánchez, I.M., Soria, D., 2003. Updated bioch ronology of the Miocene mammalf aumas from the Madrid basin (Spain). In: Reumer, J.W.F., Wessels, W. (Eds.), Dis wibution and migration of Tertiary mammals in Eurasia, 10. A volume in honour of Hans de Bruijn, Deinsea, pp. 431-441.

Pippèrr, M., Reichenbacher, B., Witt, W., Rocholl, A., 2007. The Middle and Upper Ottnangian of the Simssee area (SE Germany): Micropalaeontology, biostratigraphy and chronostratigraphy. Neues Jabrbuch für Geologie und Palä ontologie, Abhandlungen 245, 353-378.

Prieto, J., Böbme, M., Maurer, H., Heissig, K., Abrul Aziz, H., 2009. Bioswatigraphy and sedimentology of the Fluviatile Untere Serie (Early and Middle Miocene) in the central part of the North Al pine Foreland Basin: implications for palaeoenvironment and climate. International Journal of Earth Sciences 98, 1767-1791.

Robles, F., Belinchón, M., García-Flor, J., Morales, J., 1991. El Neógeno continental de Buñol y del valle del rio Cabriel. In: De Renzi, M., Márquez-Aliaga, A., Usera, J. (Eds.), El estudio de la Fonma Orgánica y sus consecuencias en Paleontología Sistemática, Paleoecología y Paleontología Evolutiva. Revista Española de Paleontología Volumen Exuraordinario, pp. 205-215

Salvador, A., 1994. Intemational Stratigraphic Guide: a guide to stratigraphic classification, terminology, and procedure. International Subcommission on Stratigraphic Classification of IUGS International Commission on Stratigraphy. International Union of Geological Sciences, Geological Society of America, Boulder.

Schlumegger, F., Burbank, D.W., Matter, A., Engesser, B., Mödden, C., 1996 Magnetos atraphic calibration of the Oligocene to Middle Miocene (3) $15 \mathrm{Ma}$ ) mammal biozones and depositional sequences of the Swiss Molasse Basin. Eclogae Geologicae Helveriae 89, 753-788.

SPSS, 2008. Statical package for the social sciences for windows, Rel. 17. SPSS Inc., Chicago.

Steininger, F.F., 1999. Chronos rapraphy, Geochronology and Biochronology of the Miocene "European Land Mammal Mega-Zones" (ELMMZ) and the
Miocene "Mammal-Zones (MN-Zones)". In: Rössner, G.E., Heissig, K. (Eds.), The Miocene land mammals of Europe. Verlag Dr. Friedrich Pfeil, Miinchen, pp. 9-24.

Steininger, F.F., Daxner-Hock, G., Haas, M., Kovar-Eder, J., Mauritsch, H., Meller, B., Scholger, R.M., 1998. Stratigraphy of the "Basin Fill" in the Early Miocene lignite opencast mine Oberdorf (N Voitsberg, Styria, Austria). Jabrbuch der Geologischen Bundesanstalt-Austria 140, $491-496$

Van Dam, J.A., 2003. European Neogene mammal chronology: past, present and future. In: Reumer, J.W.F., Wessels, W. (Eds.), Distribution and migration of Teriary mammals in Eurasia: a volume in honour of Hans de Bruijn, Deinsea 10. pp. 85-95.

Van Dam, J.A., Abdul Aziz, H., Álvarez Sierra, M.Á., Hilgen, F.J., van den Hoek Ostende, L.W., Lourens, L.J., Mein, P., van der Meulen, A.J., PeláezCampomanes, P., 2006. Long-perio as monomical forcing of mammal turnover. Nature 443, 687-691.

Van Dam, J.A., Al calá, L., Alonso Zarza, A., Calvo, J.P., Garcés, M., Krijgsman, W., 2001. The upper Miocene mammal record from the Teruel-Alf ambra region (Spain). The MN system and continental stage/age concepts discussed. Journal of Vertebrate Paleontology 21, 367-385.

Van den Hoek Ostende, L.W., Furió, M., 2005. Spain. In: Van den Hoek Ostende, L.W., Doukas, C.S., Reumer, J.W.F. (Eds.), The fossil record of the Eurasian Neogene insectivores (Erinaceomorpha, Soricomorpha, Mammalia). Part I. Scripta Geologica Special Issue 5. pp. 149-284.

Van den Hoek Ostende, L.W., Furió, M., García-Paredes, I., 2009. New data on Paenelimnoecus from the Middle Miocene of Spain in support of the subfamily Allosoricinae (Soricidae, Mammalia). Acta Palaeontologica Polonica 54, 159-164.

Van Der Meulen, A.J., Daams, R., 1992. Evolution of early-middle Miocene rodent faumas in relation to long-term palaeoenvironmental changes. Palaeogeography, Palaeoclimatology, Palaeoecology 93, 227-253.

Van der Meulen, A.J., García-Paredes, I., Álvarez-Sierra, M.A., van den Hoek Ostende, L.W., Hordi jk, K., Oliver, A., Peláez-Campomanes, P., in press. Update Aragonian biostratigraphy: Small Mammal distribution and its implications for the Miocene European Chronology. Geologica Acta.

Van der Meulen, A.J., Peláez-Campomanes, P., 2007. Residents and wansients in the fossil record. In: Levin, S.A. (Ed.), Encyclopedia of Biodiversity. Elsevier, New York, pp. 1-7.

Van der Meulen, A.J., Peláez-Campomanes, P., Daams, R., 2003. Revision of medium-sized Cricetidae from the Miocene of the Daroca-Villafeliche area in the Calatayud-Teruel basin (Zaragoza, Spain). In: López-Marinez, N., Peláez-Campomanes, P., Hernández Fernández, M. (Eds.), En torno a Fósiles de Mamíferos: Datación. Evolución y Paleoambiente. Coloquios de Paleontología Volumen Extraordinario, 1. pp. 385-441.

Van der Meulen, A.J., Peláez-Campomanes, P., Levin, S.A., 2005. Age smucture, residents, and transients of Miocene rodent communities. The American Naturalist 165, E108-E125.

Ziegler, R., Fablbusch, V., 1986. Kleinsäuger-Faumen aus der basalen Oberen Siisswasser-Molasse Niederbayerns. Zitteliana 14, 3-58. 